\title{
RACE RELATIONS, NATIONALISM AND THE HUMANITARIAN ROHINGYA CRISIS IN CONTEMPORARY MYANMAR
}

\section{Introduction:}

For a long time, Myanmar, which used to be called Burma, was closed to the outside world. It was only in 2011, when the democratisation process started to take place that the country started to open up to the rest of the world. However, the recent Rohingya crisis in the western Rakhine state has once again put the country onto the centre stage of world affairs. The Burmese government has recently been subjected to severe criticism by the international community because of its harsh policies in the Rakhine state against the Rohingya people. The aim of this paper is firstly to look at the position of ethnic minorities in contemporary Myanmar more generally and then secondly to focus more specifically on the Rohingya minority group. This paper argues that the current raging Rohingya crisis should not be viewed in isolation but should be analysed and seen as a part of a broader historical context. This paper gives a lot of importance to this broader historical context. The current humanitarian crisis in the Rakhine, what used to be called the Arakan, and also any kind of ethnic tension in Myanmar today can be traced back to the British colonial policy of divide and rule when the colonial administration openly favoured ethnic minorities. However, one cannot only blame the British colonial administration. There are other historical factors which deserve equal attention. Policies which work against the interests of ethnic minority groups can be seen very easily in the country after it gained independence in the year 1948. Xenophobic tendencies got expressed in state policies in the sixties when there was an open dislike for all things considered foreign. Politicians and their obsession with Buddhism and their attempts at trying to make it the state religion, and forcing people of Indian descent (who were brought into Myanmar by the colonial administration as cheap labour) to leave the country are just a few examples of such xenophobic policies. So the contemporary Rohingya crisis needs to be studied within this broader historical context and should be seen as a part of a broader historical continuum. But why is so much violence happening now? 'The Rohingyas have undergone decades of discrimination and disenfranchisement, but never to the degree that they currently face' (Alam, 2018, p163). To address this, the paper further argues that it is the convergence of certain political actors and their ideologies and activities (like the military, the National League for Democracy, the Arakan League for Democracy and the role of extremist Buddhist groups like the MaBaTha) which explains the escalation of violence in recent years. Before we look at the situation of the Rohingya people, let us first take a look at the country's political history, which will set the context and secondly the situation of ethnic groups more generally.

\section{The British Colonial Administration:}

Myanmar had been subjected to British colonial rule in the $19^{\text {th }}$ and $20^{\text {th }}$ centuries. The two main pillars of the British Empire in Asia were the East India Company and the Christian missionaries. Whilst the East India Company dealt with hard core political and economic issues in Asia, the Christian missionaries were involved in their proselytization campaigns converting people to Christianity so that the indigenous people of Asia would more readily embrace the Empire. Britain's initial interaction with Burma took place through defensive moves on part of the East India Company. Britain's interest in the country was related to business. Britain's initial preference had been for an informal control rather than to have direct hold over Burma. Before reaching Burma, the 
British had established their hegemony in the Indian subcontinent next door, which it did partly through diplomacy and partly through war. Where diplomacy failed, war had to be waged. Britain extended its rule over Burma in a similar way. Imperial Britain had to fight three wars with the Burmese before it could exercise full control over the country. The first Anglo Burmese War was fought between the years 1824-1826. The second war was fought in the year 1852 and the final war was fought in the year 1885 (Moe, 2018, p69-88). The process of taking over Burma was a gradual, long drawn, arduous and protracted process. Initially, the coastal strips were captured, and then lower Burma or the Irrawaddy delta and finally upper Burma or the more interior parts of the country. For a long time, Burma was governed by the British from Calcutta, which is today's Kolkata in eastern India (Church, 2017, p122). Calcutta used to be the capital of British India before it was moved to New Delhi. Burma was brought within the broader framework of British India very quickly and ruled as a part of Bengal Presidency. It remained a part of India till the year 1937. Development started to take place after 1852, but more widespread reform took place after 1885.

The impact of British colonial rule on Burma was by and large very negative as it had been elsewhere in Asia. The British introduced the pacification campaigns in Burma since it was seen as a savage and lawless part of the Empire. Order was enforced through these campaigns to impose order, passivity, security and stability. This process was formally concluded in the year 1890 . This paved the way for the permanent stationing of security personnel in Burma and the villagers were subjected to colonial rule more directly. In other words, the pacification campaigns allowed Britain to tighten its grip over the country. The colonial administration also mapped their new territorial possession. In a land containing a diverse range of ethnic minorities which had never before treated as a single administrative unit, the colonial administration carved out what they called ministerial Burma which was the core where the ethnic majority population lived and the excluded or frontier areas in the periphery, which is where the ethnic/religious minorities lived (Walton, 2013, pp7-8). The excluded areas in the peripheral parts of the country were mountainous whereas the Burman core or ministerial Burma consisted of the plains or lowlands. Before the British arrived, no indigenous kingdom had controlled the territory that today comprises Myanmar. 'Pre-colonial Burma was never a unified and coherent state in the way we understand the features of the modern state today' (Guan, 2007, p125). The colonial authorities also attempted to rationalise the administrative structures. In doing so, they destroyed the traditional authority structures in central Burma following the expulsion of King Thibaw in the year 1885. The traditional political institutions like the monarchy, the aristocracy, the nobility and the royal agencies associated with the king in central Burma soon disappeared. Local ruling families who had governed parts of the country for centuries soon lost their traditional position of power and prestige. By contrast in the peripheral parts of the country or in the frontier areas, where most minorities lived, the British made use of indirect rule. The frontier areas were not subjected to direct rule like the Burman core. The traditional political institutions in the frontier areas were also kept intact or at least not interfered with. Hence relations between the British and the minorities in the periphery were less strained. Robert Taylor writes, 'While direct rule was implemented in the plains, in the hills a system of indirect rule relying on the recognition of traditional chiefs was deemed appropriate' (Taylor, 2009, p80). The British also introduced economic development in the country. In this connection, the delta region in the south deserves special mention. The liberal economic framework was introduced and special measures were designed to accommodate capitalism. Considerable infrastructure investment was made e.g. the railways had been introduced between 1870 and 1915. When Burma was made a 
part of British India a single colonial market for goods and services and labour was created. Migration from other parts of the country and South Asia to the southern Irrawaddy delta region boosted the population. Finally, Burma was exposed to the rest of the world and the global economy. Indians arrived in places like Rangoon for work. 'So many of the South Asian immigrants settled in the colonial capital that by 1940 over half of the city's population was from the subcontinent (Cockett, 2015, p17). Alongside came many Chinese and Europeans to do business. Ian Holliday writes, 'By the time of the 1931 census, the last surviving survey of colonial Burma, a population of roughly 14.5 million people included slightly more than 30,000 Europeans and Eurasians, around 200, 000 Chinese, and in excess of one million Indians. Major cities were transformed, or more accurately created, and Rangoon was effectively taken out of a Burmese orbit and turned into a global commercial center populated by outsiders, marked by a range of social vices, and linked by sea to a network of ports in Britain and its other Asian colonies. As early as 1901, $51 \%$ of its inhabitants were Indian' (Holliday, 2011, p31). Rangoon eventually became a global financial hub populated by foreigners. So, 'when in 1935 the Burma Act separated Burma from India, it was decried by Indian financial interests but not the Burmese, whose aspirations for independence were in part driven by a wish to prevent continued Indian immigration. In the Irrawaddy delta, where the most fertile soil was located, Indian moneylenders had by stages taken over land previously owned by the Burmese, and then worked it with cheap imported Indian labour' (Cotterell, 2014, p245).

The impact of these colonial policies on Burmese society was devastating. The pacification campaigns which were introduced supposedly to bring in order and stability were too top-down as an approach and made state-society relations coercion intensive. The mapping exercise driven above all by administrative convenience paved the way for and strengthened ethnic tensions and complicated existing racial divides. The rationalisation of administrative structures in central Burma weakened support for the British and these further complicated relations between the British and the Burman ethnic majority. While the senior positions in the administration were filled in by the Europeans, the lesser posts were taken up by the ethnic minorities. The ethnic minorities were favoured in both the military and administration. Holliday writes, 'Elite administrators came from the ICS, and the repressive arm of the state was represented above all by the British Indian Army. While senior positions were taken by Europeans, other ranks were filled frequently by Indians and sometimes by minority ethnic peoples from the periphery. Indeed, until Burma was given separate colonial status, Burman participation in the state was distinctly limited, and in the army virtually non-existent. Before 1937, the Indian Army contained hardly any Burmans, though some Chin, Kachin and other minorities were recruited. Although a British Burma Army was then established, by April 1941 less than $20 \%$ of a total force of 10, 000 men was classified as Burman alongside large Chin, Kachin and Karen contingents. Even in the Territorial Army, formed for homeland defence, only some $35 \%$ of a force of slightly more than $\mathbf{3 0 0 0}$ men was Burman. In consequence, there was a large gulf between state and society in Burma proper' (Holliday, 2011, pp33-34). Supporting this line of argument, David Steinberg writes, 'because the British did not trust the Burmans, who had resisted their rule, those recruited in the Burma Army who were not Indian were essentially from the martial races. Thus, minorities formed the majority of the troops: the Karen (27.8\%), Chin (22.6\%), and Kachin (22.9\%), who were organised into ethnic military units, such as the Karen Rifles. Only about $12.3 \%$ of the Burma army was composed of Burmans at the start of World War Two. Burman antagonism against the Karen was exacerbated by the Karen participating with the British in the 
pacification of the Burmans' (Steinberg, 2010, p30). The Burman Buddhist majority as a result felt excluded. Burman participation in the state, administration and the army was clearly limited. They were discriminated against by the British as the British followed the policy of divide and conquer. This exclusion of the ethnic majority from the state and military service proved to be catastrophic in the long run since it paved the way for a powerful ethnic majority nationalism narrowly based on Buddhism to come into existence. Economic growth set the stage for economic recession. Capitalism undermined traditional institutions which ultimately promoted a nationalist reaction. Finally, exposing a traditional society to global market forces also had an adverse impact on Burma. Burma had been relatively isolated and cut off from the rest of the world because of its natural barriers like extensive coastlines and mountain ranges. The opening up of Burma to the rest of the world gave rise to a virulent nationalist backlash that had profound implications for the country once the British had left.

\section{The Rise of Burmese Nationalism and Political Developments Since the 1900's:}

The reforms introduced by the British ultimately strengthened nationalist sentiment in Burma. The Young Men's Buddhist Association came into existence in the year 1906. In the year 1920, it was superseded by the General Council of Burmese Associations. The YMBA tried to bring under one overarching national umbrella a range of Buddhist modernist groups 'in an attempt to assert a cultural identity distinct from the western culture of the colonisers. At the same time, the YMBA recognised the inability of traditional Burmese culture to create an independent society capable of coping with new conditions' (Steinbeg, 1987, p284). Inspired by Gandhi in India and led by U-Ottama, Burma's first generation of political monks came to the political forefront to challenge the British colonial administration. Nationalist reaction strengthened in the 1920's and the 1930's. Between the years 1930-1932, a peasant rebellion was led by monk Saya San. Across the decade, the Dobama Asiayone or We Burman's Association fed student protest and worker protest. It came into existence around 1930. With the passage of time, a militant side of the nationalist movement developed and the gaze of Burmese leaders fell on Japan for vanguard action. Led by Aung San in 1941, the 'thirty comrades' formed the core of the Burma Independence Army and fought with the Japanese against the British. However, the alliance between Japan and the BIA was short-lived and in 1945, the BIA switched sides and joined hands with the Allies to drive out the Japanese from the country.

After the Second World War, the colonial divide between central Burma and the frontier areas became a critical issue and there were on-going talks as the British were leaving of the two Burma principle. 'Some on the British side had been worried about the fate of the Shan and other ethnic minorities in an independent Burma and suggested detaching the upland areas and keeping them as a British crown colony. British frontier officials were particularly fond of the hill people, such as the Karen along the Thai border who had fought consistently and often very courageously against the Japanese ' (Myint-U, 2011, P87). The country was one nation with diverse ethnic groups residing in the more peripheral parts which had been separated from each other because of the colonial policy of divide and rule. Ethnic minority groups were initially reluctant to join hands with the Burmese majority. In 1946, the Anti-Fascist People's Freedom League called for a conference of representatives of all people for the purpose of discussing the establishment of the Union of Burma. In Panglong, on the $12^{\text {th }}$ of February, 1947, Aung San along with minority group representatives signed a document which recognised the autonomy of ethnic minorities. The incoming leader, $\mathrm{Nu}$, 
made a personal pledge to ethnic minorities with regard to future fair dealings. During this time the emphasis was on the Union of Burma rather than on the separate status of ethnic minorities. In other words, between the years, 1945 and 1948, nationalism was more Burmese than Burman. There was an attempt to bring people of diverse backgrounds together although with time within this broad nationalism there were more exclusive dynamics. Among them was an attempt to reassert an identity with a tendency to look back to a mono ethnic past rather than looking forward to a multi ethnic future. Also present was a series of ethnic minority nationalisms that would challenge the dominant Burman strand of nationalism after 1948. What further complicated matters was the Burmanisation policy associated with the AFPFL. Nu's obsession with Buddhism and trying to make it the state religion made him unpopular amongst the ethnic minorities. Possibly he believed that Buddhism could be used to unify the country that was so divided along political, racial, linguistic, religious and cultural lines. This is quite similar to the situation in other post-colonial societies like Pakistan, where the political and military elite have tried to use Islam as the glue to hold the fractured country together.

The democratic phase was short lived and lasted from 1948 till the year 1962. In $1962 \mathrm{Ne}$ Win took over after launching a coup. Before he and the military rose to power, Burmese soldiers viewed themselves as state builders and it was only through them that a patriotic spirit could be cultivated. During the 1960's, there had been revulsion to western ways and with the arrival of the military, xenophobic tendencies became more pronounced and took root. For instance, in 1962, Ford, Fulbright and Asia Foundation activities had been stopped. In 1964, English medium schools had been banned and elite private schools were taken into public ownership. The new military regime did not trust the educated professional class. 'Scores of well trained, well-educated bureaucrats, including the entire top echelon of officials schooled in the old colonial civil service, were sacked in the coming months....also to go were the western foreign aid agencies and advisers.... The John Hopkins School of Advanced International Studies, today with campuses in Washington, Bologna, and Nanking, then had a campus in Rangoon; the teachers were told to pack up, and hopes for educating a new generation of world-class Burmese diplomats were ended' (Myint-U, 2007, p291). Libraries run by the UK, the US, India and Russia had been closed down by 1965 , and it was becoming increasingly hard to get visas to travel to Burma. Visas for western tourists became severely restricted. Between 1963 and 1964, an estimated 300, 000 Indians left following the nationalisation of their trading concerns. After 1964, under the orders of Ne Win, hundreds of thousands of men, women and children were sent back to both India and Pakistan. The Indian government under Nehru's leadership made arrangements with ships and special planes to bring these people back to India. Many Chinese also left especially after the race riots that took place against the Chinese in 1967. The situation was a bit similar to Idi Amin's expulsion of Asians from Uganda. Political dialogue with the ethnic minorities also stopped for a while during the years of military rule.

Since independence in 1948, the ethnic minority armies have had to continuously fight against the Burmese armed forces. Despite the ceasefires, ethnic insurgencies in the borderlands still continue. Between 1989 and 1996, most major militias signed ceasefire deals with the armed forces. Of course many of these agreements have not been signed, or been made public and were actually quite informal in nature. There has been tension especially since 2008 when the constitution made room for the ethnic militias to join hands with the armed forces and form a Border Guard Force. This allowed the central armed forces to keep an eye on the activities of the ethnic militias. In other 
words, it was a partial but not total integration of these ethnic militias within the broader Burmese Army. If these ethnic leaders went ahead with this arrangement then they would have a heightened place and elevated status in the new order.

Thus, to conclude this section, we can safely say that Burmese society has experienced two kinds of nationalism: Anti-colonial nationalism in earlier times before 1948 and religious nationalism in more recent times, post 1948. Nationalism is a particular stage in history and is a change that societies ordinarily undergo when they start turning towards industrialisation and capitalism and the middle class emerges as a key component in the whole process. Nationalism emerges as a way of restructuring the different communities into a new identity and value system, the identity being that of the citizen. In the Burmese case, one moved away from being a British subject to becoming a citizen of the new nation state. Anti-colonial nationalism was all inclusive and included as many people and different groups as possible. Post 1948, however, a variety of nationalisms have emerged in contemporary Myanmar, one of which is the rise of religious nationalism, which overlaps with Buddhist extremism. Religious nationalism tends to be exclusive and gives priority to certain communities over others. Since 1948, the Burman Buddhist has been made the primary citizen of the country and this has left other ethnic groups feeling excluded, although these other ethnic groups have from time to time challenged the dominant strand of Burman-Buddhist nationalism. Ordinarily in a democratic set up, the new identity of the citizen should be equated with justice and equality, and human rights should be guaranteed. But in the case of Burma's hybrid political system where the military still has a central position in politics and in a society where religious nationalism is entrenched, the Burman-Buddhist is given priority and is a level above all other communities.

\section{Ethnic Minority Groups in Contemporary Myanmar:}

Myanmar is one of the most ethnically diverse countries in mainland South East Asia. A nation of approximately 51 million, it is also one of the most diverse countries from a religious standpoint (Rogers, 2015). There is a presence of Buddhism, Christianity and Islam in contemporary Myanmar. In addition to the dominant Burman speaking majority based mainly in central and lower Burma, there are seven major ethnic groups and these include the Karen, Karenni, Shan, Mon, Chin, Kachin and the Arakan. Most of these ethnic minority groups reside in the more peripheral parts of the country and tend to have a sense of oneness with their ethnic brothers living across the international border. For instance, the Kachin people live in northern Burma close to the border with China and share ethnic ties with the Jingpo people. Nandita Haksar writes, 'The Kachin's are spread over the Yunnan province of China where they are known as the Jingpo; over Myanmar where they are called Kachins; in India they are known as the Singpho' (Haksar, 2013, p88).

Burmese insurgent groups like the KIA/Kachin Independence Army, since the early 1980's, has also maintained strong connections with the Indian insurgent groups like the ULFA/United Liberation Front of Assam and the NSCN/National Socialist Council of Nagaland (Sadan, 2013, p2). The Chin and the Arakanese people live in the west close to India and Bangladesh. The Karen, Karenni, and Mon live in the south and south east close to the border with Thailand, and the Shan in the east, close to the border with Laos. In addition to these ethnic groups, there are also the smaller communities like the Naga's, the Rohingya's, the Lahu, the Lisu and the Pao. The Rohingyas are amongst the most persecuted. They are a predominantly Muslim group residing in the Arakan or what is now called the Rakhine state in western Myanmar. Their situation is so bad that it has often been compared to genocide. They have been rendered stateless by successive governments and have been often 
persecuted by state officials. Down the years they have experienced an extreme form of human rights violations with rights to property, education, marriage and employment all curtailed. Often they have been pushed into Bangladesh. They have tried reaching Bangladesh in flimsy boats and hence they have often been referred to as the boat people and many have died on the way. 'The central government believed that they are illegal immigrants who will be returned to Bangladesh. Therefore, their citizenship rights are denied and many of them are internally displaced and confined to live in camps with limited mobility' (Jung, 2018, p141). We will discuss their plight in much more detail later on in this paper.

Since independence in 1948, many of these ethnic groups have fought an armed struggle against the Burman dominated central government. Many of these groups feel excluded from the decision making process and feel that their voices are not heard by the central authorities. This has given rise to strong separatist tendencies in the more peripheral parts of the country. 'Throughout the decades the regime has had to cope not just with several bouts of popular unrest (government forces killed thousands of demonstrators during riots in 1988) but also with separatist insurgencies by Myanmar's minorities, notably in the Shan and Kachin states in Myanmar's eastern and northern regions but also in the Rakhine region bordering Bangladesh (Andrews, 2015, p252). Many of these ethnic groups do not feel a sense of identification with mainstream Burmese society. Due to ethnic and cultural commonalities with their ethnic brothers across the international border, there are very strong cross border connections and constant too-ing and frow-ing across the borderlands. For instance, there are Naga and Chin people on both sides of the Indo-Burmese border. In some cases these ethnic communities have fought for secession, in some cases for more autonomy and in some extreme cases for independence. In almost all cases, they have fought for equal rights, and federal democracy within the Union of Burma. Some of these groups have signed ceasefires with the central authorities in the 1990's. Of course many of these ceasefire deals have been broken. For instance, the Kachin had seventeen years of ceasefire from 1994 onwards until the military launched a brutal offensive against them in 2011.The Karen and Karenni have fought continuously to varying degrees until ceasefire deals were signed in 2011/2012. Before we look at the Rohingya crisis, let us take a brief look at the situation of some of the other ethnic groups in contemporary Myanmar since there are strong parallels between these groups and the Rohingyas.

The Karen people live in south east Burma close to the border with Thailand. 'The Karens constitute the second largest ethnic minority population in Myanmar today, next to the Shans' (Kipgen, 2015, p24). They did not sign the historic Panglong agreement although they did send their representatives to act as observers. Their armed movement against the centre is the longest in Myanmar's history. Since the late forties, they have been continuously fighting for human rights, and for more autonomy. The Karen National Movement or the KNU is the country's oldest ethnic insurgency movement. Some from the Karen community believe that the Karen's will eventually be wiped out by the brutal policies of the central regime. Historically, the Karen people suffered enormously at the hands of the Burman kings, so when the British started to colonise Burma in the 1800 's, the Karen people saw the British as liberators. They were loyal to the British, who in turn favoured them in service, the military and education. Their loyalty to the British did not go down well with the central authorities and has angered much of the political elite in Myanmar. In the Second World War, for instance, they fought along with the Allies and in return the British promised them independence which did not eventually come. Leaders of the Karen people like Saw Ba U Gyi had made it clear that surrendering was out of the question, that the Karen people must retain their 
arms, that the recognition of the Karen state must be complete and finally the Karen people will decide their own political destiny and what is best for them and not the Burman central government. Although the British let the Karen people down, the Karen people have soldiered on their own against the central regime in their struggle for recognition and for their rights. In the 1960 's, the movement regained its momentum under the leadership of General Bo Mya, who dominated the Karen National Union for over three decades. To free themselves from Burman persecution and oppression, they have often fled to neighbouring countries like Thailand, where their security has also been at risk.

'The Kachins inhabit the more precipitous mountains of the far north of Burma and what the $\mathrm{KIO} /$ Kachin Independence Organisation today calls the Kachin Substate-north Hsenwi and other parts of Shan state as far south as Kengtung' (Tucker, 2001, p20). They are a predominantly Christian group and converted at the turn of the $20^{\text {th }}$ century by American Baptist missionaries. Like the Karen people, they also favoured the British and fought alongside the Allies during the Second World War. '..during the colonial era, the British heavily recruited Kachin soldiers for the colonial army. After Myanmar gained its independence in 1948, the Kachin faced reprisal for their role during the colonial period, while at the same time coming under repression by the government, under the control of the majority Bamar ethnic group' (Han, 2017, p65). The Kachin Independence Organisation or the KIO is the main resistance group for the ethnic Kachin people. To fund their purchases of arms from across the Thai border, they brought jade and opium from the Kachin state down to the Thai border. The central government has often aimed at trying to stop their access to food, funding, intelligence and recruits. 'What came to be known as the 'Four Cuts Policy', or cutting links between the insurgents and the local populace for food, funds, information and recruits, was executed across ethnic regions since armed revolutions shook the country' (Woods, 2016, p120). The armed wing of the KIO is the KIA, Kachin Independence Army. The Kachin state has almost become a conflict zone where human rights violations are common. These human rights violations include rape, land confiscation, religious discrimination and forced labour. Thousands have been displaced from their villages. The situation has been so dire that it has often been compared to a foreign occupation. The Kachin people have found it hard to practise their Christian faith. This is because the central regime views the practising of Christianity with suspicion and as an act of disloyalty. Christianity has also been linked with the colonial legacy.

The Chin people reside in western Burma, close to the Indian state of Mizoram. Since the forties they have suffered because of their politics, ethnicity and religion. The Chin people are predominantly Christian like the Karen and the Kachin people. They have been subjected to religious discrimination. They tend to have a sense of one-ness with the Mizo people living across the international border in India. The Chin's have been associated with numerous pro-democracy organisations and hence viewed unfavourably by the Burmese state. The Chin state is one of the poorest parts of the country, where basic infrastructure like healthcare and education is almost nonexistent. The Chin people take their religious Christian identity very seriously and have often constructed crosses on hill tops, which have been torn down by the military. The military has then gone on to construct Buddhist pagodas or statues of the Buddha using Chin people as forced labour. Chin Christians have often been converted to Buddhism and traditional practices of the Chin people have been undermined. For instance, traditionally Chin people do not permit alcohol in their society but the military has often brought in large quantities of intoxicating liquor like 'OB', which it has sold especially on Sundays. Church workers have often faced grave danger. Raping of women and 
children by Burmese soldiers is common. Chin language is forbidden in schools and Chin history is not taught. The emphasis has been on Burman history. In response to governmental suppression, many ethnic groups like the Chin have sought to develop separate educational systems which would then enable them to preserve their distinct culture.

\section{The Rohingyas:}

The Rohingya people live in the western parts of the country, particularly in the Rakhine (Arakan) province, which has Sittwe as its capital city. They are generally viewed as Bengali Muslims who have more in common with the people of Bangladesh than with Myanmar. 'The line separating Myanmar and Bangladesh came into being as a humble boundary line between districts of British India. When this huge colony was split into British Burma and British India in 1937, the border took on a semi-international status for the first time. It became fully international when the British relinquished power in India and Pakistan in 1947 and Burma in 1948' (Ullah, 2011, p141). The Rohingyas have lived in the Rakhine province for generations although their origins have been contested by various analysts. Some analysts believe that they have a secret plot to create an Islamic state. The Rohingya people themselves claim that they have lived in the Arakan for generations and that Muslim kings actually ruled the Arakan in $\mathbf{1 4 3 0}$ for over a hundred years. It is also believed that when they came to the Arakan, they came in different phases. For instance, some arrived as traders and merchants, others as conquerors, and still others as victims of pirates. 'Between the $15^{\text {th }}$ and $19^{\text {th }}$ centuries the spread of Islamic influence grew stronger across the Bengal-Arakan frontier region, particularly in northern Arakan' (Rahman, 2010, p234). The Rohingya crisis began shortly after 1948 when the central government tried to deprive the people of their right to citizenship. Without citizenship rights the Rohingya people have faced restriction in almost all spheres of life including health, education and employment. They have been subjected to forced labour, rape and land confiscation like some of the other ethnic groups. Many have fled to neighbouring Bangladesh where they have not always been welcome and hence as a community have been surviving stateless. Thousands more live in very critical conditions in temporary shelters and unregistered camps or settlements and many have dispersed in the southern Chittagong part of Bangladesh.

In recent years there has been a great deal of tension in the Rakhine. 'The violence of early June, 2012, was the first major wave of conflict between Buddhists and Muslims to strike Myanmar as it transitioned away from military rule' (Wade, 2017, p10). Although the violence originated from a range of factors like poverty, racism, political oppression and perceived illegal immigration, the Arakan Rohingya Salvation Army, previously known as Harakah al-Yaqin or Faith Movement in English, launched coordinated attacks on 30 police posts and an army base in the Rakhine on the $25^{\text {th }}$ of August, 2017, using man made bombs and small weapons that resulted in the death and injury of many. These attacks were quite similar to the previous attacks carried out by the ARSA in 2016, but with greater magnitude and intensity (Kipgen, 2019, p62). The leader of ARSA, Ata Ullah, said that the group was waging a defensive war against the repressive Myanmar military regime which he accused of committing human rights violations against Rohingya Muslims. In response to this, the Myanmar army has launched clearance operations, which has led to thousands of Rohingyas fleeing to Bangladesh. 
Although the crisis in the Rakhine has been sparked by recent events, the origins of this situation can be traced back to the early fifties, shortly after independence. Since 1948, Burmese politicians have always targeted the Rohingyas when they needed to deflect attention from other urgent matters like the deteriorating economy. Many party officials have called for their expulsion from the Rakhine and the main opposition in Myanmar today by and large has not done much to help them. In Myanmar, extremist Buddhist organisations have also been at the very core of interethnic violence since 2011, when the process of democratisation started. Both the major political parties, the regime's USDP, Union Solidarity and Development Party and the opposition, NLD, National League for Democracy have been relying on these organisations for their electoral support, giving extremist groups a central position in the decision making and political process. There has also been substantial evidence that the old military regime has funded and supported some of these extremist groups to stir up inter-ethnic tension. In turn, the existence of inter-ethnic violence keeps open the possibility of the military returning to power, in order to supposedly save the country from further violence and political disintegration. Some analysts like Azeem Ibrahim have argued that 'the violence against the Rohingyas is not an unpleasant, though predictable, side-effect of a society moving from authoritarian rule to liberalism. The repression of the Rohingyas is orchestrated, in part by those who believe there is no place in Myanmar for anyone who is not a Buddhist (and especially if they are Muslim), in part by ethnic extremists in other communities who want a racially pure state, and in part by the military regime, which is content to see a degree of unrest' (Ibrahim, 2016, p3).

A central part of the political narrative put forward by the military, Buddhist extremist groups and the political elite more generally is that the Rohingyas are actually Bengali people and hence have no right to live in the country. They should live in their own country-Bangladesh. This line of argument and way of thinking is pervasive and quite entrenched in contemporary Myanmar. This is also one reason why the persecution of the Rohingyas is much worse when compared with other ethnic minorities. 'What started out primarily as a scapegoating exercise by the military regime has unfortunately been absorbed by the Myanmar public' (Ibid, 2016, p4). Discriminatory thinking against the Rohingyas has taken root especially since 1962 when the military regime made it clear that only Buddhists especially if they were ethnically Burman could be true loyal citizens. The Rohingyas are visible minorities who are seen as outsiders and are different from the mainstream especially when it comes to their language, ethnicity and religion. The nation building process started by the military since the early sixties and the way they defined patriotism was quite narrow and this created a fear of outsiders amongst the majority people. The argument that has been continuously put forward by the military generals is that the Rohingya people entered the country during the years of British colonialism and hence are not indigenous and not really Burmese.

As we already know, British rule ended in the year 1948. For the Rohingya people, independence brought a particular set of problems. They had remained loyal to the British when the Japanese invasion took place in 1942 like some of the other ethnic minority groups discussed earlier e.g. Karen and the Kachin. This in turn had stirred up inter-ethnic strife with the predominantly Buddhist Rakhine community and paved the way for fragmentation of the Rakhine province. The British had promised the Rohingyas independence but went back on their promises once the Second World War was over. This led to a short lived revolt by the Rohingyas and some Rohingya politicians petitioned for the inclusion of the northern parts of the Arakan into former East Pakistan, today's Bangladesh. Apart from this bit of unrest shortly after independence, the Rohingyas have not been 
involved in any major uprising like the other ethnic groups, who have waged an armed struggle for decades.

In the short democratic phase between the years 1948 and 1962, the Rohingyas were treated like any other ethnic minority and the situation was not so bad. It was during the years of military rule that their persecution became more pronounced. The generals were desperate to justify their own rule and one way of doing this was if they stoked inter-ethnic violence between different ethnic groups. They could then use the excuse to stay in power because of on-going internal challenges. Once again, this is very similar to other post-colonial societies like Pakistan where military generals have argued that they need to stay in power till external pressures and internal challenges get resolved. Being 'Buddhist' was used by the military as the test for being a true citizen. The 1974 Constitution was a step back in terms of minority rights since it required Rohingyas to have identity cards and it classified them as foreigners. The 1982 Burmese Citizenship law made matters worse by starting with the obsession: who lived in the Arakan in 1824 and before that year? It was argued by the wider establishment that the Rohingyas had not lived in the Arakan before 1823. New laws introduced in 1989 and the 2008 Constitution retained the discriminatory ethnicity laws from 1974. The 2014 census forced the Rohingyas to choose between being described as 'Bengali' or not being able to register to vote. 'The first option carried the threat of deportation, the second of being forced into one of the refugee camps that had sprung up after the 2012-13 violence in the Rakhine. Even worse, the regime then confiscated the 'White Cards' that had been the last form of official documentation held by many Rohingyas' (Ibid, 2016, p10). Since the 1982 Citizenship Law there has been negative propaganda and violence directed at the Rohingyas and this has in turn forced many Rohingyas to leave Myanmar for Bangladesh. And although Myanmar has made some attempts in moving towards democracy, it is quite clear that the Rohingyas have no place in its democratic future. Holliday argues that the country's citizenship crisis is one of the most pressing problems today which needs urgent attention. According to Holliday, this 'citizenship crisis' has four sides to it. 'First, in a state where all citizens can claim no more than fragile civil liberties, partial political freedoms and limited social rights, there is a broad curtailment of citizenship. Second, Rohingya Muslims living above all in western Rakhine State are denied citizenship, and partly in consequence other Muslims throughout the country face growing problems. Third, in peripheral areas minority ethnic groups are able to claim no more than restricted citizenship. Fourth, and contrastingly, in the broad national heartland the Bamar majority tends ever more to arrogate or appropriate citizenship' (Holliday, 2014, p404).

One reason why the Rohingyas have become a target of the state is because they are seen as an easy target. Apart from following a different religion which is viewed unfavourably by the political elite, they are militarily weaker than other ethnic groups since they have not really been involved in an armed resistance against the state like the Kachin's and the Karen's. The Rohingyas are so poor that they do not even have the funds to buy weapons to sustain a long armed struggle against the state. As mentioned in the earlier section, the Karen's and the Kachin's have been involved in an armed resistance against the state for decades and they have fought continuously for their rights, to gain more recognition and to gain more autonomy if not political independence. Furthermore, the Rakhine is often seen as a backward province when compared with the other provinces because it has historically been very poor. It is not particularly rich in mineral resources and is primarily dependent on fishing and agriculture. The port and capital city of Sittwe is the only major industrial urban centre. 
When we look at the complexities of Burmese politics today, we can identify five distinct but overlapping actors involved in the political processes of the country. These actors include the military, the two multi ethnic parties-the USDP and NLD, ethnic regional parties like the ALD/Arakan League for Democracy, Buddhist monks and civil society groups. Other than the last category, that is civil society groups, all the other categories have contributed to the problems faced by the Rohingyas either directly or indirectly in recent years. This convergence of political actors and their ideologies and activities helps us to understand why the Rohingya violence has escalated more than ever in recent years. So it becomes necessary to analyse the role of these actors both collectively as well as individually.

Despite the recent democratising tendencies, the military remains very powerful and former generals sit in the parliament as part of the USDP. 'Like the Burma Socialist Programme Party which preceded it, the Union Solidarity and Development Party which ruled from 2010 was a Frankenstein creation, the handiwork of the army, with no political roots in the population' (Popham, 2016). The military generals still have a lot of control over the country's wealth. Although in theory the memberships of the USDP and NLD are multi-ethnic and multi-confessional, since 2011 both parties have been increasingly speaking out on behalf of the Burman ethnic majority, most of whom are Buddhist. There are also many ethnic regional parties associated with different ethnic groups that reflect their own specific interests. The exception to this of course has been the Rohingyas. Buddhist monks have increasingly come to the political forefront and participated in the political process. Amongst the Buddhist extremist groups, there are two main organisations which demonise Myanmar's Muslim minority and they are the 969 Movement and the MaBaTha or the Patriotic Association of Myanmar. Civil society groups such as the Pan Zagar have called for an end to antiMuslim prejudice, but by and large these groups are quite weak and need much more international backing.

The military, ever since its existence, has been involved in all kinds of disputes with ethnic minorities and to unify what the generals perceived as a fractured and highly fragmented country, socialism as an ideology was used in the beginning and later on Buddhism was stressed. Although the generals may give the impression to the outside world that the country is currently going through a process of democratisation, the problem is that the real power still rests with the military. The military controls the country from the side-lines in much more subtle ways rather than intervening directly in Burmese politics. It needs to retain political power to guard its corporate interests and thus does not have the slightest intention of really stepping down. At the same time there is evidence that the MaBaTha Buddhist extremist organisation was set up by the military as an alternative power base. If religious extremist groups cause problems, it gives the military a chance to return to politics to 'save' the country from inter-ethnic strife and further internal turmoil.

Although it is believed by some that the NLD is genuinely concerned about the plight of minorities and the Rohingyas in particular, this may not necessarily be the case. The NLD does not really have a connection or understand the situation of minorities who are marginalized because of the NLD's elitist character. The NLD emerged in the 1988 uprising, initially led by a former general, Tin Oo and Aung San Suu Kyi. The NLD thus actually combines military elements with civilian elements. Its initial leadership basically came from individuals who had fallen out with General $\mathrm{Ne}$ Win. Whilst the party may have appealed to the protesting student population, it did not have a real connection with the bulk of the Burmese population, let alone with ethnic minorities in the more 
peripheral parts of the country. At best the NLD, can be described as a hybrid political party rather than being truly democratic. Of course, the NLD did get support of the monks who are widely respected in Burmese society and this helped their overall political position. Another problem associated with the NLD, which has added to the crisis faced by the Rohingyas is that whilst the NLD tries to be multi ethnic and all-encompassing in theory, in practise its electoral base still remains the Burmese-Burman ethnic majority. Without the support of the majority, where anti-Muslim prejudice is quite entrenched, they cannot really stay in power. It relies on the Buddhist monastic community to influence the electorate which has since 1988, unfortunately, become anti-Islamic and they often demand that the NLD support their positions. If the NLD does not support the monastic anti-Islamic position, it may lose the support it gets from the monastic community. Of course not all monks are anti-Islamic, but anti-Muslim prejudice has become quite pronounced in recent years. Global events linked with Islamist terrorism only strengthen anti-Muslim prejudice and add more fuel to an already blazing fire.

When it comes to looking at regional ethnic political parties, the one that deserves most attention for purposes of this paper is the ALD or the Arakan League for Democracy, which represents the Rakhine Buddhist community. Azeem Ibrahim writes, 'its manifesto was explicitly anti-Rohingya from the start and called for the exclusion of the Rohingyas from the electoral process and the establishment of Rakhine villages in areas with a Rohingya majority. Rohingya activists and politicians note that this party was closely allied to the NLD and joined with the NLD in challenging the validity of those elections which had been won by ethnically Rohingya candidates' (Ibrahim, 2016, p13). Now called the Rakhine Nationalities Development Party, its leadership has been accused of organising the 2012 and 2013 ethnic violence which compelled many Rohingyas into refugee camps. Its leaders have also made it clear that the Rohingyas are not welcome and have increasingly joined hands with Buddhist extremist groups.

Although a small number of Buddhist monks may reject anti-Muslim rhetoric, the 969 Movement and the MaBaTha are groups who take more of a hardliner's approach. The 969 Movement and the MaBaTha might not be political parties strictly speaking, but they have considerable influence and hold over Burmese politics and society. They tend to see the presence of Islam on Burmese soil as a major threat to the very existence of Buddhism. Supposedly, the presence of the Muslim Rohingyas is eroding and increasingly undermining the Buddhist ethos in contemporary Myanmar. They openly advocate discrimination and violence against the Rohingyas. The 969 Movement grew out of the 1988 political uprising and has had considerable influence over the NLD. The MaBaTha is more recent and was founded in 2010 and has become more powerful than the 969 Movement. For instance, the MaBaTha has a great deal of control over religious education in contemporary Myanmar, which they have often used to teach the more stringent antiMuslim interpretations of Buddhism. More specifically, the violence in the Rakhine in the years 2012 and 2013 was orchestrated by an alliance of the MaBaTha and the Arakan League for Democracy.

\section{Some Concluding Points and the Way Forward:}

This paper has argued that the on-going Rohingya crisis in the Rakhine state in western Myanmar should not be viewed in isolation but should be analysed within a broader historical framework and should be seen as a part of a broader historical continuum. The British colonial policy of divide and rule, politicians and their obsession with Buddhism and trying to make it the state 
religion after independence in 1948, and the xenophobic state policies introduced by General $\mathrm{Ne}$ Win after 1962 should all be factored in whilst analysing the situation of ethnic minorities in contemporary Myanmar more generally and the plight of the Rohingyas more specifically. The paper further argues that it is the convergence of the activities and political ideologies of certain political actors like the military, the NLD, the ALD and the Buddhist extremist organisations like the MaBaTha which has led to the current crisis and the escalation of violence. This paper highlights that the Muslim Rohingya community currently faces extreme forms of marginalisation and alienation as a result of the nation-building policies of the military/hybrid regime in contemporary Myanmar. These nation building strategies ultimately forced thousands of Rohingyas to leave Myanmar for Bangladesh. Ethnic conflicts in post-colonial societies have often come into existence because authoritarian regimes have followed stringent nation building policies which have arisen as a result of their narrow understandings of nationhood and belonging. To prevent the rise of such conflicts, it is very important for the state to take a more federally minded approach and pursuing policies that are more inclusive and accommodating. Having access to health care facilities and education and having cultural rights as well as the equitable distribution of the national wealth are a key part of the peace-building process (Egreteau, 2012, p312). For the international community to help, firstly they would need to take a more nuanced approach towards the NLD, and instead of viewing it as a force for good in Burmese society that cares about the well-being of ethnic minorities, the international community would need to consider the NLD's linkages with the military and extremist religious groups. This understanding is very important. There is a strong, brave and dedicated civil society movement in Myanmar which needs more support from the international community for its efforts. Also, there needs to be more international pressure on the regime in Myanmar to allow human rights experts to make an assessment of the situation for themselves. At the more regional level, members of the ASEAN/Association of South East Asian Nations (of which Myanmar is currently a part of) would need to abandon their traditional policy of non-interference and look into the Rohingya humanitarian crisis more urgently. The role of the ASEAN member states is crucial here since they were the ones who bore the brunt of the 2015 refugee crisis and many are currently aware that unless and until the problematic situation in the Rakhine gets resolved, there could be further flows of refugees, which would lead to further instability in the region.

\section{References:}

Alam, J., 2018, 'The Rohingya Minority of Myanmar: Surveying their Status and Protection in International Law', International Journal on Minority and Group Rights, 25(2), 157-182.

Andrews, J., 2015, The World in Conflict: Understanding the World's Trouble-spots, The Economist Books: London.

Church, P., 2017, A Short History of South-East Asia, Wiley: Singapore.

Cockett, R., 2015, Blood, Dreams and Gold: The Changing Face of Burma, Yale University Press: New Haven and London.

Cotterell, A., 2014, A History of South East Asia, Marshall Cavendish: Singapore.

Egreteau, A., 2012, 'Assessing Recent Ethnic Peace Talks in Myanmar', Asian Ethnicity, 13(3), pp311313. 
Guan, A.C., 2007, 'Political Legitimacy in Myanmar: The Ethnic Minority Dimension', Asian Security, 3(2), pp121-140.

Haksar, N., 2013, Across the Chicken Neck: Travels in Northeast India, Rainlight Rupa Publications: New Delhi.

Han, E., 2017, 'Geopolitics, Ethnic Conflicts along the Border, and Chinese Foreign Policy Changes toward Myanmar', Asian Security, 13(1), pp59-73.

Holliday, I., 2011, Burma Redux: Global Justice and the Quest for Political Reform in Myanmar, Columbia University Press: New York.

Holliday, I., 2014, 'Addressing Myanmar's Citizenship Crisis', Journal of Contemporary Asia, 44(3), pp404-421.

Ibrahim, A., 2016, The Rohingyas: Inside Myanmar's Hidden Genocide, Hurst: London.

Jung, E., 2018, 'Islam and Politics in Contemporary South East Asia' in A.Ba\& M.Beeson, edited, Contemporary South East Asia, third edition, Palgrave: London.

Kipgen, N., 2015, 'Ethnicity in Myanmar and its importance to the Success of Democracy', Ethnopolitics, 14(1), pp19-31.

Kipgen, N., 2019, 'The Rohingya Crisis: The Centrality of Identity and Citizenship', Journal of Muslim Minority Affairs, 39(1), pp61-74.

Moe, D., T., (2019), 'Burman Nationalism and Ethnic Identity: Toward an Ethnic Post-colonial Theology of Resistance and Reconciliation in Myanmar', Black Theology: An International Journal, 17(1), pp69-88.

Myint-U, T., 2007, The River of Lost Footsteps: A Personal History of Burma, Faber \& Faber: London.

Myint-U, T., 2011, Where China meets India: Burma and the new Crossroads of Asia, Faber and Faber: London.

Popham, P., 2016, The Lady and the Generals: Aung San Suu Kyi and Burma's Struggle for Freedom, Rider: London.

Rahman, U., 2010, 'The Rohingya Refugee: A Security Dilemma for Bangladesh', Journal of Immigrant \& Refugee Studies, 8(2), pp233-239.

Rogers, B., 2015, Burma: A Nation on the Crossroads, Rider: London.

Sadan, M., 2013, Being and Becoming Kachin: Histories Beyond the State in the Border-worlds of Burma, Oxford University Press: Oxford.

Steinberg, J., 1987, In Search of South East Asia: A Modern History, University of Hawaii Press: Honolulu.

Steinberg, D., 2010, Burma/Myanmar: What Everyone Needs to Know, Oxford University Press: Oxford/New York. 
Taylor, R.H., 2009, The State in Myanmar, Hurst: London.

Tucker, S., 2001, Burma: The Curse of Independence, Pluto Press: London.

Ullah, A.A., 2011, 'Rohingya Refugees to Bangladesh: Historical Exclusions and Contemporary Marginalisation', Journal of Immigrant and Refugee Studies, 9(2), pp139-161.

Wade, F., 2017, Myanmar's Enemy Within: Buddhist Violence and the Making of a Muslim 'Other', Zed: London.

Walton, M., 2013, 'The Wages of Burman-ness: Ethnicity and Burman Privilege in Contemporary Myanmar', Journal of Contemporary Asia, 43(1), pp1-27.

Woods, K., 2016, 'The Commercialisation of Counter-insurgency: Battlefield Enemies, Business Bedfellows in Kachin State, Burma', in Mandy Sadan, edited, War and Peace in the Borderlands of Myanmar: The Kachin Ceasefire, 1994-2011, Nordic Institute of Asian Studies: Copenhagen. 